\title{
CONSUMER INSOLVENCY PROCEEDINGS IN EUROPE: AN INTRODUCTION TO CONSUMER OVER-INDEBTEDNESS AND DEBT RELIEF
}

\author{
Jan-Ocko Heuer
}

1. INTRODUCTION

2. CONSUMER OVER-INDEBTEDNESS, ITS CAUSES AND CONSEQUENCES

3. SOCIAL AND LEGAL RESPONSES TO CONSUMER OVER-INDEBTEDNESS

4. THE HISTORY, AIMS AND (PLAIN) REALITY OF CONSUMER BANKRUPTCY
1.01

1.04

6. CONCLUSIONS BANKRUPTCY
5. LEGAL, ECONOMIC AND SOCIALPOLITICAL ISSUES IN CONSUMER

\section{INTRODUCTION}

1.01 In the past decades, the growth of consumer credit has led to increased debt problems of private households, and many economically advanced countries have responded to this social risk of household over-indebtedness by creating legal procedures for the resolution of consumer insolvencies: consumer bankruptcy laws. The spread of consumer bankruptcy law has been particularly pronounced in Europe, where since the 1980s almost all countries have adopted bankruptcy laws for non-business individuals. ${ }^{1}$ This 'seismic legislative activity' 2 alone calls for a comparative study of consumer insolvency proceedings in Europe.

1.02 However, insolvency law for natural persons has not only expanded in territorial terms; it has also undergone a transformation of its basic aims and

1 For an overview see: Kilborn, Jason J. (2011): Expert recommendations and the evolution of European best practices for the treatment of overindebtedness, 1984-2010. Deventer: Kluwer.

2 Tabb, Charles J. (2005): 'Review: Lessons from the globalization of consumer bankruptcy', Law E Social Inquiry 30: 763-82, p. 765. 
characteristics. While in the past the main objectives of personal bankruptcy law were the punishment of defaulting debtors and the (fair) distribution of an insolvent debtor's assets among his or her creditors, the primary aim of present-day consumer bankruptcy regimes is the provision of a financial 'fresh start' for honest insolvent individuals by means of a discharge of debts (i.e., the legal cancellation of the debtor's responsibility for the payment of specified types of debts). In order to account for this historical transformation of personal bankruptcy law, I have suggested incorporating the debt discharge and the possibility of a voluntary petition (i.e., debtor-initiated proceedings) into a contemporary definition of consumer bankruptcy. Thus, the term consumer bankruptcy can be defined as 'a statutory regime for the collective settlement of debt problems of a consumer that includes the possibility of a voluntary petition and a debt discharge'. ${ }^{3}$ While in the country chapters a broader definition is used - which refers to all legal proceedings dealing with insolvencies of consumers, including those that do not offer a debt discharge the reader will note that many regulations in contemporary consumer insolvency regimes are concerned with the discharge and its timing, scope and conditions.

The debt discharge does not only tackle the negative effects of consumer over-indebtedness on debtors, economies and societies by restoring economic and social participation of debt-ridden individuals, but also raises profound legal, economic, social-political and ethical issues and is rightly at the centre of consumer bankruptcy theory and research. However, consumer bankruptcy is more than the regulation of debt relief. This chapter will first consider consumer bankruptcy within the broader social and legal landscape by outlining the social risk of consumer over-indebtedness and the resultant variety of policy responses and then provide a short overview of the history, aims and main dimensions of consumer bankruptcy law.

\section{CONSUMER OVER-INDEBTEDNESS, ITS CAUSES AND CONSEQUENCES}

The introduction of consumer bankruptcy laws in Europe is a response to the rise of household over-indebtedness. Over-indebtedness has to be analytically separated from credit and debt, although in reality the boundaries between indebtedness and over-indebtedness are often fluid. Moreover, the diversity of legal and academic definitions of the term over-indebtedness point to the

3 For details see: Heuer, Jan-Ocko (2014): Rules and norms of consumer insolvency and debt relief: A comparison and classification of personal bankruptcy systems in 15 economically advanced countries. Dissertation. Bremen International Graduate School of Social Sciences (BIGSSS), University of Bremen, pp. 105-52. 
multidimensional and dynamic character of the phenomenon. In a study for the European Union, consumer over-indebtedness is characterized as:

a situation in which consumers will definitely not be able to meet their financial obligations in the near future. It is defined by an overall deterioration of their and their dependants' economic situation and will gradually lead to social exclusion, higher cost of living ('the poor pay more') and less participation in overall economic development and social progress. ${ }^{4}$

By contrast, the term insolvency is usually restricted to the financial dimension of debt problems and refers to a debtor's inability to pay her financial liabilities. However, for the purpose of this chapter both terms can be used synonymously to denote severe debt problems and financial distress as well as their psychosocial effects on individuals and households.

1.05 Empirical research on consumer over-indebtedness shows that in all advanced economies a considerable share of private households has severe debt problems. ${ }^{5}$ However, there are marked differences among countries even within the European Union, with the 13 member states that acceded after 2004 showing significantly higher levels of households reporting arrears on financial commitments than households in the 15 longer-standing EU member states. ${ }^{6}$ In all countries, over-indebtedness affects both low-income and middle-class households and is a widespread social risk, even though financial distress occurs more often in low-income households. ${ }^{7}$

1.06 Research on the causes of over-indebtedness can be divided into two distinct but complementary approaches. One approach focuses on the level of individuals and households. Here, empirical studies show that various socioeconomic factors statistically increase the likelihood of over-indebtedness,

4 Reifner, Udo; Niemi-Kiesiläinen, Johanna; Huls, Nick J. H.; Springeneer, Helga (2003): Consumer overindebtedness and consumer law in the European Union. Final report. Presented by the Institute for Financial Services e.V., University of Rotterdam/School of Law, and University of Helsinki/Helsinki Collegium for Advanced Study to the Commission of the European Communities, Health and Consumer Protection Directorate-General.

5 E.g., Betti, Gianni; Dourmashkin, Neil; Rossi, Mariacristina; Yin, Ya Ping (2007): 'Consumer overindebtedness in the EU: Measurement and characteristics', Journal of Economic Studies 34: 136-56. Anioła, Paulina; Gołaś, Zbigniew (2012): 'Differences in the level and structure of household indebtedness in the EU countries', Contemporary Economics 6: 46-59.

6 Civic Consulting of the Consumer Policy Evaluation Consortium (2014): The over-indebtedness of European households: Updated mapping of the situation, nature and causes, effects and initiatives for alleviating its impact. Final report. Conducted for Commission of the European Communities, Directorate-General Health and Consumers.

7 E.g., Gomez-Salvador, Ramon; Lojschova, Adriana; Westermann, Thomas (2011): Household sector borrowing in the euro area: A micro data perspective. European Central Bank, Frankfurt am Main. Occasional Paper Series, No. 125. 
including: being a young adult; having dependent children; living in a single adult household, especially as a lone parent; being divorced, separated or widowed; earning a low income; being unemployed; being in poor health; and being a tenant instead of a homeowner. ${ }^{8}$ In line with these findings, studies on the emergence of debt problems often detect 'critical life events' that are interpreted as causes or triggers of over-indebtedness, including: job loss or other reductions in income; unemployment; permanent low income; family break-up (e.g., separation or divorce); the failure of a business; illness or injury and costs for medical treatment; the loss of a partner or family member; the birth or adoption of a child; the establishment of a (joint) household; financial mismanagement; over-consumption; compulsive buying; compulsive gambling; alcohol/drug abuse; psycho-social problems; general problems of coping with everyday life; lack of experience with financial products; marketing pressures from lenders; over-extension of credit and irresponsible lending; and failure to benefit from social services and social welfare benefits. ${ }^{9}$ However, critics have pointed out that attempts to determine individual causes of over-indebtedness do not only invite questionable 'blame games' but also underestimate the complexity, multidimensionality and processuality of debt problems, not least since longitudinal studies of individual debt cases have shown several interrelations between individually and socially attributed 'causes' of over-indebtedness. ${ }^{10}$

In line with these criticisms, a second line of research focuses on changes in social, economic and political conditions that have spurred the growth of household over-indebtedness. One important factor is the considerable growth of consumer credit as well as the opening of reputable credit markets for previously excluded low-income households in recent decades. This has

8 E.g., Davydoff, Didier; Naacke, Grégoire; Dessart, Elodie; Jentzsch, Nicola; Figueira, Filipa; Rothemund, Marc; Mueller, Wolf; Kempson, Elaine; Atkinson, Adele; Finney, Andrea (2008): Towards a common operational European definition of over-indebtedness. Report by the Observatoire de l'Epargne Européenne, Centre for European Policy Studies, and University of Bristol/Personal Finance Research Centre for the Commission of the European Communities, Directorate-General Employment, Social Affairs and Equal Opportunities. Bryan, Mark; Taylor, Mark; Veliziotis, Michail (2010): Over-indebtedness in Great Britain: An analysis using the Wealth and Assets Survey and the Household Annual Debtors survey. Report for the Department for Business, Innovation and Skills (BIS). Essex: Institute for Social and Economic Research (ISER), University of Essex.

9 E.g., Sullivan, Teresa A.; Warren, Elizabeth; Westbrook, Jay Lawrence (1989): As we forgive our debtors: Bankruptcy and consumer credit in America. New York, NY: Oxford University Press. Sullivan, Teresa A.; Warren, Elizabeth; Westbrook, Jay Lawrence (2000): The fragile middle class: Americans in debt. New Haven, CT: Yale University Press. Disney, Richard; Bridges, Sarah; Gathergood, John (2008): Drivers of overindebtedness: Report to the Department for Business, Enterprise and Regulatory Reform. London: Department for Business, Enterprise and Regulatory Reform.

10 E.g., Reiter, Gerhard (1991): Kritische Lebensereignisse und Verschuldungskarrieren von Verbrauchern. Berlin: Duncker \& Humblot. Hirseland, Andreas (1999): Schulden in der Konsumgesellschaft: Eine soziologische Analyse. Amsterdam: G+B Verlag Fakultas. 
been fostered by deregulation and liberalization of financial markets, increasing globalization and financialization of national economies, and technological and financial innovations such as securitization, credit scoring or credit cards. While some scholars argue that these supply-side changes can sufficiently explain the rise of over-indebtedness, ${ }^{11}$ others point to additional factors which have increased demand for credit by private households, such as changes in labour markets, welfare states and household structures resulting in growing economic volatility, rising inequality of wealth and income, and 'loans-for-wages' substitution strategies. ${ }^{12}$

1.08 There is agreement that over-indebtedness has many negative effects on households, economic development and social integration. For debtors and their dependants, over-indebtedness is usually not only a financial problem but negatively affects well-being, health, housing, employment and social participation. Over-indebtedness also imposes costs and burdens on financial markets, labour markets, welfare states, health care systems and judicial systems. In short, consumer over-indebtedness is a social risk triggered by socioeconomic transformations of advanced capitalism that has negative consequences for households, economies and societies, and thus requires effective policy responses.

\section{SOCIAL AND LEGAL RESPONSES TO CONSUMER OVER-INDEBTEDNESS}

1.09 Most European countries have created numerous social and legal measures to prevent, alleviate and treat household debt problems and their consequences. An important role in the development of policy responses to over-indebtedness has been played by international organisations which have put consumer debt problems on their agenda and influenced national policies by issuing reports and policy recommendations; this includes the European Union, ${ }^{13}$ the Council

11 E.g., Baird, Douglas G. (2007): 'Technology, information, and bankruptcy', University of Illinois Law Review 2007: 305-21.

12 E.g., Niemi-Kiesiläinen, Johanna; Ramsay, Iain; Whitford, William C. (2003): 'Introduction', in: Johanna Niemi-Kiesiläinen; Iain Ramsay; William C. Whitford (eds.): Consumer bankruptcy in global perspective. Oxford: Hart, pp. 1-14. Ramsay, Iain (2007): 'Comparative consumer bankruptcy', University of Illinois Law Review 2007: 241-73.

13 Huls, Nick J. H.; Reifner, Udo; Bourgoignie, Thierry; Reich, Norbert; Domont-Naert, Françoise; van Huffel, Michel; Haane, Bianca; Roseval, Louise; Ackermann, Hanneke (1994): Overindebtedness of consumers in the EC member states: Facts and search for solutions. Commission of the European Communities, DirectorateGeneral Consumer Policy Services. Brussels: Story Scientia. Betti, Gianni; Dourmashkin, Neil; Rossi, Mariacristina; Verma, Vijay; Yin, Ya Ping (2001): Study of the problem of consumer indebtedness: Statistical aspects. Final report. Submitted to the Commission of the European Communities, Directorate-General for Health and Consumer Protection. London: ORC Macro. Reifner et al., supra note 4. Korczak, Dieter (2006): Amnesty of debts: Amicable agreement and statutory solution; a discussion of the Dutch model, Netherlands. Synthesis 
of Europe, ${ }^{14}$ the International Association of Restructuring, Insolvency and Bankruptcy Professionals (INSOL International), ${ }^{15}$ and, most recently, the World Bank. ${ }^{16}$ However, while regulations on consumer credit have been harmonized within the European Union, the European Regulation on Insolvency Proceedings - first adopted in 2000 (effective 31 May 2002) ${ }^{17}$ and recast in 2015 (effective 26 June 2017) ${ }^{18}$ - only establishes a framework for crossborder insolvencies and regulates the recognition of insolvency proceedings in other EU member states, but does not harmonize national measures for the treatment of consumer over-indebtedness. Yet, current attempts by the European Commission to foster entrepreneurship might lead to a harmonization of basic principles of insolvency law within the EU that would also affect the debt discharge of consumers. ${ }^{19}$

It is useful to sort policy responses to over-indebtedness from two perspectives.

On the one hand, it can be distinguished between legal measures, such as credit market regulation and consumer bankruptcy, and social measures, such as debt counselling and financial education; on the other hand, it can be distinguished between measures aiming at the prevention of over-indebtedness, such as credit market regulation and financial education, and measures aiming at the treatment of over-indebtedness, such as debt counselling and consumer bankruptcy. There is agreement that an effective approach against household

report. Commission of the European Communities, Directorate-General Employment, Social Affairs and Equal Opportunities. Rotterdam: ÖSB Consulting, CEPS/INSTEAD, IES. Davydoff et al., supra note 8. London Economics (2012): Study on means to protect consumers in financial difficulty: Personal bankruptcy, datio in solutum of mortgages, and restrictions on debt collection abusive practices. Final Report. Financial Services User Group (FSUG); Commission of the European Communities, Directorate-General Internal Market and Services. London: London Economics.

14 Niemi-Kiesiläinen, Johanna; Henrikson, Ann-Sofie (2005): Report on legal solutions to debt problems in credit societies. Council of Europe, Bureau of the European Committee on Legal Co-Operation (CDCJ-BU). Strasbourg: Council of Europe. Council of Europe (2008): Legal solutions to debt problems: Recommendation Rec(2007)8 adopted by the Committee of Ministers of the Council of Europe on 20 June 2007 and explanatory memorandum. Strasbourg: Council of Europe.

15 INSOL International (2001): Consumer debt report: Report of findings and recommendations. London: INSOL International. INSOL International (2011): Consumer debt report II: Report of findings and recommendations. London: INSOL International.

16 Kilborn, Jason J.; Garrido, José M.; Booth, Charles D.; Niemi, Johanna; Ramsay, Iain (2013): Report on the treatment of the insolvency of natural persons. World Bank, Insolvency and Creditor/Debtor Regimes Task Force, Working Group on the Treatment of the Insolvency of Natural Persons. Washington, DC: World Bank.

17 Council Regulation (EC) No 1346/2000 of 29 May 2000 on insolvency proceedings, in: Official Journal of the European Communities 30.06.2000, OJ 2000 L 160/1-18.

18 Regulation (EU) 2015/848 of the European Parliament and of the Council of 20 May 2015 on insolvency proceedings (recast), in: Official Journal of the European Union 05.06.2015, OJ 2015 L 141/19-72.

19 European Commission (2016): Proposal for a Directive of the European Parliament and of the Council on preventive restructuring frameworks, second chance and measures to increase the efficiency of restructuring, insolvency and discharge procedures and amending Directive 2012/30/EU; Strasbourg; 22.11.2016; $\operatorname{COM}(2016) 723$ final - 2016/0359 (COD). 
over-indebtedness has to involve various measures. For example, a study for the European Union proposes six building blocks: (1) responsible borrowing (e.g., financial education and money management courses for debtors); (2) responsible lending (e.g., credit market regulation and creditor commitments); (3) responsible arrears management (e.g., non-aggressive debt recovery actions); (4) provision of debt counselling services; (5) creation of nonjudicial/informal debt settlement procedures; and (6) consumer bankruptcy procedures. ${ }^{20}$

1.11 All studies and recommendations on consumer over-indebtedness agree in two respects: on the one hand, consumer bankruptcy is only the last resort in the fight against over-indebtedness; on the other hand, any effective strategy against over-indebtedness has to include consumer bankruptcy regulations, because informal and social measures usually only work in the shadow of coercive debt relief. ${ }^{21}$

\section{THE HISTORY, AIMS AND (PLAIN) REALITY OF CONSUMER BANKRUPTCY}

1.12 In the last decades, consumer bankruptcy has become the last resort for the 'casualties' of modern consumer society and financialized capitalism, and each year millions of insolvent individuals file a petition for debt relief and obtain a financial 'fresh start' via a discharge of debts.

1.13 However, personal bankruptcy law has not always been concerned with debt relief and a 'fresh start'; in fact, for most of its millennia-long history bankruptcy was a device for debt collection and asset distribution among creditors, and thus 'relief was not for debtors, but from debtors'. ${ }^{22}$ Only with the rise of capitalism was it increasingly recognised that the reorganisation of an insolvent debtor might be more profitable for her creditors than the liquidation of the debtor's business and the distribution of the remaining assets. However, even the debt discharge did not originate as a device for economic re-integration, but as part of a 'carrot and stick' approach in English bankruptcy law in the early eighteenth century that promised to reward cooperation of debtors with debt relief while simultaneously threatening 'uncooperative' debtors with the death penalty. ${ }^{23}$ It was mainly against the

20 Davydoff et al., supra note 8, pp. 58-101.

21 Kilborn, supra note 1.

22 Tabb, Charles J. (1995): 'The history of the bankruptcy laws in the United States', American Bankruptcy Institute Law Review 3: 5-51, p. 8.

23 Tabb, Charles J. (1991): 'The historical evolution of the bankruptcy discharge', American Bankruptcy Law Journal 65: 325-71. 
background of the 'consumer credit revolution' 24 in the early twentieth century in the United States that the 'fresh start' for insolvent debtors by means of a debt discharge became recognised as an important and independent aim of personal bankruptcy law. ${ }^{25}$

In the current wave of consumer insolvency legislation, the debt discharge has been almost universally accepted as the primary aim of personal bankruptcy. By contrast, the other aim of bankruptcy law - i.e., providing a coercive and collective mechanism to resolve the common-pool problem that an insolvent debtor's assets are usually insufficient to cover all creditor claims ${ }^{26}-$ is often of little practical relevance in proceedings involving consumer debtors, because in the majority of cases there are no assets (and earnings) available for distribution among creditors. ${ }^{27}$ This is not least because not all assets and earnings of the debtor are on the table for distribution, as human beings - in contrast to companies and other juridical persons - cannot be liquidated and need some property and income shielded from the reach of creditors for their livelihood (i.e., 'exempt' property and income). Thus, in reality 'relief of the debtor by means of the bankruptcy discharge ... is not merely an objective of the system; it is, rather, the principal (if not the sole) point of the exercise'. ${ }^{28}$ As a consequence, creditors often abstain from consumer insolvency proceedings to avoid 'throwing good money after bad', and most proceedings are more administrative than judicial or adversarial, as the discharge is the standard outcome of the process. ${ }^{29}$

\section{LEGAL, ECONOMIC AND SOCIAL-POLITICAL ISSUES IN CONSUMER BANKRUPTCY}

Viewed from an economic perspective, the idea behind consumer bankruptcy's debt discharge is plain and simple: by implicitly inserting the possibility of a

24 Calder, Lendol G. (1999): Financing the American dream: A cultural history of consumer credit. Princeton, NJ: Princeton University Press.

25 Skeel, David A., Jr. (2001): Debt's dominion: A bistory of bankruptcy law in America. Princeton, NJ: Princeton University Press. Hansen, Bradley A.; Hansen, Mary Eschelbach (2007): 'The role of path dependence in the development of US bankruptcy law, 1880-1938', Journal of Institutional Economics 3: 203-25.

26 For a theoretical account see: Jackson, Thomas H. (1986): The logic and limits of bankruptcy law. Cambridge, MA: Harvard University Press.

27 E.g., Kilborn, Jason J. (2003): 'Mercy, rehabilitation, and quid pro quo: A radical reassessment of individual bankruptcy', Ohio State Law Journal 64: 855-96.

28 Hallinan, Charles G. (1986): 'The 'fresh start' policy in consumer bankruptcy: A historical inventory and an interpretive theory', University of Richmond Law Review 21: 49-160, pp. 50 .

29 Rasmussen, Robert K. (2007): 'Introduction: The art of bankruptcy', in: Robert K. Rasmussen (ed.): Bankruptcy law stories. New York, NY: Foundation Press, pp. 1-10, p. 3. Baird, Douglas G. (2014): Elements of bankruptcy. $6^{\text {th }}$ edn, New York, NY: Foundation Press, p. 30. 
debt discharge into each credit contract, consumer bankruptcy is a form of 'mandatory debt insurance' that transfers the risk and costs of default in consumer credit markets from borrowers to lenders. The reasoning behind this risk shift is that commercial creditors are assumed to be 'superior risk assessors' and 'superior risk bearers': From an ex ante perspective (i.e., at the time of lending), creditors are 'superior risk assessors', because they can use credit reporting and credit scoring to estimate the likelihood of default and set their lending standards accordingly. ${ }^{30}$ From an ex post perspective (i.e., in case of default), creditors are 'superior risk bearers', because they can pool the costs of default and spread them among borrowers by raising the price of credit. ${ }^{31}$ According to economic theory, this increase in the price of credit results in a decrease in the use of credit, and thus the economic logic of consumer bankruptcy's debt discharge 'comes down to a comparison between the benefits of insurance and the costs of a reduced borrowing capacity'. ${ }^{32}$

1.16 However, this view of consumer bankruptcy has three theoretical and practical limitations: first, the effects of the discharge on borrowing levels and credit supply have only been studied with economic models, but not under 'realworld' conditions. This is surprising, as the introduction of consumer bankruptcy laws in many European countries provides fertile territory for studying the impact of the discharge on credit levels and debtor behaviour. In fact, both theoretical reasoning and limited empirical evidence suggest that the impact of the discharge might be rather limited: from a theoretical perspective, creditors ultimately have to "write off the costs of insolvency even when no debt relief regime exists; and empirically, it seems that the introduction of the discharge in European countries did not substantially change levels of lending to households, although elaborate studies are still lacking.

1.17 Second, the debt discharge intrudes into legal rights and obligations and might require a strong justification. Thus, several rationales for the discharge have been suggested, which can be grouped into various categories: (1) 'humanitarian theory' views the discharge as a societal act of mercy mandated by moral or ethical concerns; (2) 'social utility theory' argues that granting a discharge to debt-ridden individuals benefits society by tackling negative externalities of insolvency; (3) 'limited liability theory' views the discharge as part of the institutional framework vital to fostering economic risk-taking and entrepreneurship; (4) 'systematic over-borrowing theory' argues that the discharge

30 Howard, Margaret (1987): 'A theory of discharge in consumer bankruptcy', Ohio State Law Journal 48: 1047-88.

31 Hallinan, Charles G. (1986): 'The 'fresh start' policy in consumer bankruptcy: A historical inventory and an interpretive theory', University of Richmond Law Review 21: 49-160.

32 Chatterjee, Satyajit (2008): 'The economic logic of a fresh start', Business Review 2008: 1-8. 
compensates for systematic fallacies of the human mind that lead individuals to ignore or misjudge their rational interests and prospects; (5) 'debtor cooperation theory' justifies the discharge as an incentive for cooperation of the debtor with creditors and officials; and (6) 'economic efficiency theory' views the discharge - in accordance with the economic view of consumer bankruptcy - as a mechanism for the efficient allocation of risks in the credit market. ${ }^{33}$

Finally, the economic view underestimates the impact of actors, norms and institutions on consumer bankruptcy legislation. Basically, consumer bankruptcy law reminds us that credit and debt are not just plain financial matters; they are fundamental aspects of social life and deeply embedded into power relations and normative structures of societies. Thus, the regulation of credit and debt can offer insights into power structures, norms and values of a society, especially as personal bankruptcy law regulates one of the most crucial social situations: a debtor's inability to fulfil her economic and legal obligations and the resultant impasse between legal principles (e.g., pacta sunt servanda) and the need to remedy negative externalities of insolvency. To resolve this standoff and to undo the social state of insolvency without undoing the social order, personal bankruptcy forces debtors to ritualistically display respect for the very norms that the debt discharge necessarily subverts, and thereby it expresses fundamental values and core myths of a society. ${ }^{34}$

These aspects indicate that bankruptcy law is more than just rules on the duration of the payment plan or the determination of debts excluded from discharge, and more than specific behavioural obligations or restrictions for debtors - in its entirety it exhibits (different) normative orientations and power relationships in (different) societies, and thus it is useful to study consumer bankruptcy not only from a (comparative) legal perspective, but also from a politico-economic and socio-cultural perspective.

In this respect, the field of 'comparative consumer bankruptcy'35 has shown profound differences between the long-established personal bankruptcy regimes in Anglo-Saxon countries and the new ones in European countries,

33 Cf. Tabb, Charles J. (1990): 'The scope of the fresh start in bankruptcy: Collateral conversions and the dischargeability debate', George Washington Law Review 59: 56-113.

34 Cf. Korobkin, Donald R. (2003): 'Bankruptcy law, ritual, and performance', Columbia Law Review 103: 2124-59.

35 For overviews see: Anderson, Kent (2004): 'Review essay: The explosive global growth of personal insolvency and the concomitant birth of the study of comparative consumer bankruptcy', Osgoode Hall Law Journal 42: 661-80. Ramsay, Iain (2007): 'Comparative consumer bankruptcy', University of Illinois Law Review 2007: 241-73. Niemi, Johanna (2012): 'Consumer insolvency in the European legal context', Journal of Consumer Policy 35: 443-59. 
but also distinct approaches within Europe. ${ }^{36}$ However, it is up to further research to study which approach (or approaches) to consumer bankruptcy can best combine economic growth with social integration while being efficient, effective and fair and fit within the surrounding legal, economic and sociopolitical environment.

\section{CONCLUSIONS}

1.21 This chapter has argued that consumer over-indebtedness is an important social and economic problem in European societies which requires various political responses, including consumer insolvency proceedings that enable a financial 'fresh start' for honest insolvent individuals. The reality of consumer insolvency is often rather straightforward, but consumer bankruptcy law involves economic, socio-political and ethical aspects and is shaped by various interests, institutions and ideas. Against this background, studying the rules and norms of consumer bankruptcy should be of interest to academics and practitioners in law, finance, economics and social policy. This volume provides the most systematic and detailed survey of consumer insolvency proceedings in European countries to date and will be an invaluable resource for anyone interested in consumer bankruptcy law from a comparative perspective.

36 E.g. Niemi-Kiesiläinen, Johanna (1999): 'Consumer bankruptcy in comparison: Do we cure a market failure or a social problem?’, Osgoode Hall Law Journal 37: 473-503. Niemi-Kiesiläinen, Johanna (2003): 'Collective or individual? Constructions of debtors and creditors in consumer bankruptcy', in: Niemi-Kiesiläinen; Ramsay; Whitford (eds), supra note 12, pp. 41-60. Kilborn, Jason J. (2007): Comparative consumer bankruptcy. Durham, NC: Carolina Academic Press. Ramsay, Iain (2012): 'Between neo-liberalism and the social market: Approaches to debt adjustment and consumer insolvency in the EU', Journal of Consumer Policy 35: 421-41. Heuer, supra note 3. 